\title{
Reconciling Bagehot with the Fed's response to Sept. 11 *
}

\author{
Antoine Martin \\ Federal Reserve Bank of Kansas City
}

January 2003

\begin{abstract}
Bagehot (1873) states that in order to prevent bank panics a central bank should provide liquidity to the market at a "very high rate of interest". This seems to be in sharp contrast with the policy adopted by the Federal Reserve after September 11 when, for a few days, the Federal Funds Rate was very close to zero. This paper shows that Bagehot's recommendation can be reconciled with the Fed's policy if one recognizes that Bagehot has in mind a commodity money regime so that the amount of reserves available is limited. A high price for this liquidity allows banks that need it most to self-select. In contrast, the Fed has a virtually unlimited ability to temporarily expand the money supply.
\end{abstract}

JEL classification: E4, E5, G2.

Key Words: Liquidity Provision, Lender of Last Resort, Bagehot, September 11.

*I thank Russell Cooper, Stacey Schreft, and Gordon Sellon, as well as seminar participants at the European Central Bank, the Bank for International Settlements, and at the University of Lausanne for useful comments. I thank Matthew Cardillo for excellent research assistance. All remaining errors are mine. The views expressed here are those of the author and not necessarily those of the Federal Reserve Bank of Kansas City or the Federal Reserve System. E-mail: antoine.martin@kc.frb.org 


\section{Introduction}

This paper shows, in the context of a model economy, that two apparently incompatible policies-Bagehot's recommended policy of lending at a high interest rate, and the Fed's policy of lending at a very low interest rate-can both be justified.

Bagehot (1873) claims that a central bank can prevent panics by providing liquidity to the market. Specifically, "there are two rules. First. That these loans should only be made at a very high rate of interest... Second. That at this rate these advances should be made on all good banking securities and as largely as the public ask for them." ${ }^{1}$ It is widely believed that by applying this policy the Bank of England avoided panics in 1866, 1878, and 1890 (see, for example, De Kock (1974), Redish (2001)). This, in turn, explains why Bagehot's views are still influential today. As pointed out by Peter Bernstein in his foreword to a 1999 re-issue of Lombard Street, "After nearly 150 years, [Bagehot's] wise words are still the prescription of choice for containing financial crises, as well as a handbook for avoiding them..."

In the aftermath of the September 11th terrorist attacks in 2001, the Federal Reserve Bank followed the second rule prescribed by Bagehot, but not the first. It lent freely and vigorously, but at very low interest rates. For a few day, from September 13 - 19, the federal funds rate approached zero on several occasions (see Markets Group of the Federal Reserve Bank of New York (2002)). The Fed's response to September 11 is generally considered to have been very successful, so one might wonder why there is such a stark difference between Bagehot's proposed policy and the Fed's action.

There is some theoretical support for the Fed's policy. Martin (2001) shows that a liquidity provision policy can prevent bank runs and yields the efficient allocation if the central bank (CB) makes loans at an interest rate of zero. ${ }^{2}$ In different contexts, Antinolfi, Huybens, and Keister (2001), Freeman (1996), Green (1997), Rochet and Vives (2002) obtain results that have a similar flavor. So was Bagehot wrong?

This paper reconciles Bagehot's recommendation with the Fed's policy. It adapts the model in Martin (2001), which provides theoretical support for the Fed's action, to consider commodity money. Because the amount of reserves is limited in a commodity money regime, the central bank must lend funds at a high interest rate to prevent panics. By doing so it allows banks to self-select so that only the ones that need it most obtain liquidity.

\footnotetext{
${ }^{1}$ Page 199.

${ }^{2}$ Throughout this paper the terms "bank panics" and "bank runs" are used interchangeably.
} 
The results of this paper rely on four key assumptions. Two assumptions concern the marginal cost of increasing the supply of money. This cost is zero for fiat money and large for commodity money. The other two assumptions concern the nature of bank panics. Panics occur because of a liquidity shortage and are contagious in the sense that a run on a given bank can trigger runs on other banks.

In case of panic, the $\mathrm{CB}$ can help by providing liquidity. If the marginal cost of increasing the money supply is zero, all panics can be eliminated and the CB should lend at a zero interest rate. If the marginal cost of increasing the money supply is sufficiently large, the CB will want to economize on its scarce reserves. If panics are contagious, the CB's objective is to prevent the "primary" failures, so that no "derivative" failure will occur. It will be shown that an incentive compatible way to operate this selection it to charge a sufficiently high interest rate on $\mathrm{CB}$ reserves.

Contagion is essential for Bagehot's policy to be effective. Suppose instead that there is no contagion. Then, if there is enough liquidity for all banks that need it, runs will be avoided. Otherwise, some banks will experience a run. In either case, charging a high interest rate cannot help prevent panics, but it reduces the utility of depositors in banks that obtain liquidity. Thus a CB that tries to maximize depositors' welfare would charge no interest.

This paper also shows that, in a commodity money regime, if the CB chooses the amount of its reserves optimally, those reserves will be scarce in equilibrium in the sense that panics will occur with a positive probability. This is because with commodity money, increasing CB reserves must reduce consumption.

Liquidity provision policies have received a lot of attention recently, (see for example Cooper and Corbae (2002), Repullo (2000), Rochet and Vives (2002), Sleet and Smith (2000), Williamson (1998)), but their work does not considers the difference between commodity and fiat money regimes.

The rest of the paper is organized as follows. The next section provides some historical background. Section 3, presents the model. Section 4, defines a stationary equilibrium for this model. Section 5, presents the results for a fiat money regime, while section 6 does so for a commodity money regime. Section 7 shows that a CB that tries to maximize households' utility will choose reserves, so that the probability of a panic is strictly positive. Section 8 concludes. 


\section{Some historical background}

\subsection{Bagehot's recommended policy}

Although many of the ideas in Lombard Street had been expressed before, notably by Thornton (1802), Bagehot is often credited for exposing them in a more systematic way. ${ }^{3}$ Bagehot's proposed policy contains two main elements. In times of crisis:

1) A CB should lend freely and vigorously.

2) Loans should be made at a very high interest rate.

Bagehot credits the Bank of England for having prevented a panic in 1866 by following this policy. Subsequently, in 1878 when the City Bank of Glasgow failed, and in 1890 when Baring Bank failed, the same policy is credited for preventing widespread crisis. This is in contrast to the crises of 1847 and 1857, when the Bank of England initially refused to lend, leading to bank runs.

This paper focuses on the second element of Bagehot's proposed policy: the interest rate at which loans should be made. There are, in the literature, two main arguments to justify Bagehot's claim that the CB should lend at a high interest rate. First, under the gold standard, a high rate of interest prevents a drain of gold. Second, a high rate of interest helps prevents moral hazard.

The first argument can be found in Humphrey (1975) and Humphrey and Keleher (1984). They note that following Thornton (1802), Bagehot distinguishes between two types of shocks: internal (or domestic) and external (or foreign) cash drains. The former shock occurs when pessimistic depositors withdraw their deposits to hold cash and can, according to Bagehot, be countered if the CB lends vigorously. The latter shock occurs when gold flows out of England to be deposited in a foreign country. To counter such a shock the CB should raise its lending rate, so as to attract foreign gold and retain domestic gold. When the two shocks arise simultaneously, the CB should lend vigorously and at a high rate of interest.

The argument about moral hazard can be found in Sheng (1991) and Summers (1991), among others. The basic idea is that banks may take excessive risk if they know that they can borrow at a low rate during difficult times. Proponents of this view usually argue that the high interest rate Bagehot mentions is a penalty rate.

To justify his policy, Bagehot argues that "[a very high interest rate] will operate as a

\footnotetext{
${ }^{3}$ Laidler (2002) studies the differences and the similarities between the views of Bagehot and Thornton.
} 
heavy fine on unreasonable timidity, and will prevent the greatest number of applications by persons who don't require it. The rate should be raised early in the panic, so that the fine may be paid early; that no one may borrow out of idle precaution without paying well for it; that the banking reserve may be protected as far as possible." 4

No reference is made in this passage to an external cash drain or to moral hazard. Indeed, there are very few references to moral hazard in Lombard Street, and Bagehot has been criticized by Hirsch (1977) for not realizing that his proposed policy could create such a problem. ${ }^{5}$ Instead, the quote points to the need to allocate the CB liquidity in an appropriate way. Hence, this paper argues that lending at a high rate of interest allows banks to self select. Fisher (1999) seems to share this view as he notes that the high interest rate "limits the demand for credit by institutions that are not in trouble." This interpretation is consistent with an interpretation of Goodhart (1999), that Bagehot does not propose a penalty rate.

The approach adopted by this paper in interesting for two reasons. First, from the perspective of history of thought, one wants to consider the internal consistency of Bagehot's argument. Hence the case for a high interest rate should be made based on the type of economic mechanisms that Bagehot emphasizes, rather than some other mechanism. Second, this paper provides a formal analysis of the self-selection story which has not been studied yet.

\subsection{The Fed's policy after 9-11-2001}

The events of September 11 caused a breakdown in the usual means of communication between banks, and resulted in the temporary shutdown of the interbank market. Some banks found themselves with high liquidity needs, while others had large excesses of liquidity. Because the interbank market was not functioning, the latter banks were not able to lend to the former. To alleviate the effects of the liquidity shortage, and prevent a more generalized panic, the Federal Reserve provided unusually large amounts of reserves.

The Fed typically provides liquidity to markets though the discount window (DW) and through open market operations (OMOs). ${ }^{6}$ In an OMO the Fed provides funds to primary

\footnotetext{
${ }^{4}$ Page 199.

${ }^{5}$ The model in this paper does not consider moral hazard problems. Martin (2001) shows that a well liquidity provision policy similar to the one considered here can prevent bank panics without moral hazard.

${ }^{6} \mathrm{~A}$ third source of liquidity is float.
} 
security dealers through a repurchase agreement (RP). These dealers then lend these funds to banks on the interbank market. Ordinarily, the Fed auctions off a fixed amount of reserves and does not engage in transactions at prices that would imply a lending rate lower than its target.

The DW allows banks to obtain funds directly from the Fed. At the time, the interest rate at the DW was 50 basis point lower than the federal funds market target rate. ${ }^{7}$ For obvious reasons, banks are prohibited to lend these funds on the interbank market. Because the Fed typically prefers that banks obtain liquidity on the interbank market, borrowing at the DW is usually discouraged.

The following discussion details some of the actions of the Fed in the days following September 11. A good description of the Federal Reserve's policy after September 11 is provided by the Markets Group of the Federal Reserve Bank of New York (2000). Chart 1 shows borrowed balances (funds obtained through the DW) and nonborrowed balances (funds obtained through OMOs). ${ }^{8}$ On September 11 and 12, large amount of liquidity were provided through the DW because the interbank market was not functioning properly. On subsequent days, as interbank communications improved, OMOs provided much more liquidity than the DW. While the interest rate on DW loans did not change-until September 17, when the Federal Funds Rate target was decreased by 50 basis points-banks were encouraged to borrow which made the effective cost of borrowing lower than usual.

As far as OMOs are concerned, the Fed accepted virtually all dealer's bids for RPs, some at rates well below the Federal Funds Rate target. The Fed's vigourous provision of liquidity would have satisfied Bagehot: "From Wednesday [9-12] through the following Monday [9-17], the size of open market operations were aimed at satisfying all the financing that dealers wished to arrange with the Desk, in order to mitigate to the extent possible the disruptions to normal trading and settlement arrangements." ${ }^{9}$ Chart 2 shows overnight RPs and term RPs. Overnight RPs over this period can be associated with emergency lending. The size of these RPs between September 12 and 19 testify to the large amount of liquidity the Fed provided to the interbank market.

\footnotetext{
${ }^{7}$ It was 3 percent until 9/14, 2.5 percent between 9/17 and 10/1, and 2 percent after that.

${ }^{8}$ Charts 1, 2, and 3 come from Markets Group of the Federal Reserve Bank of New York (2000).

${ }^{9}$ Markets Group of the Federal Reserve Bank of New York (2000), page 22.
} 
Chart 1

Total Fed Balances Around September 11, 2001

Billions of Dollars

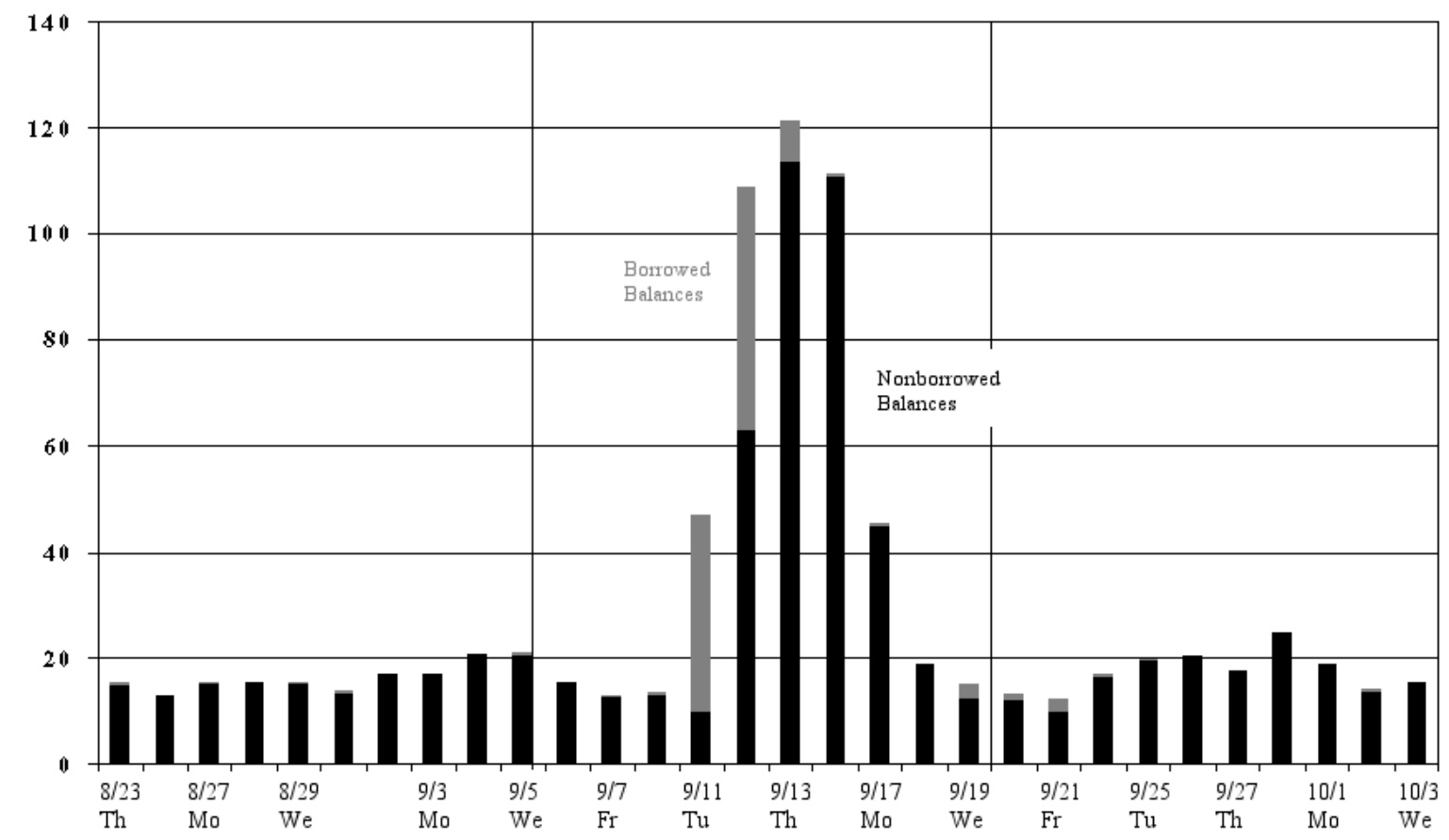

Chart 2

Outstanding Term and Overnight RPs Around September 11, 2001

Billions of Dollars

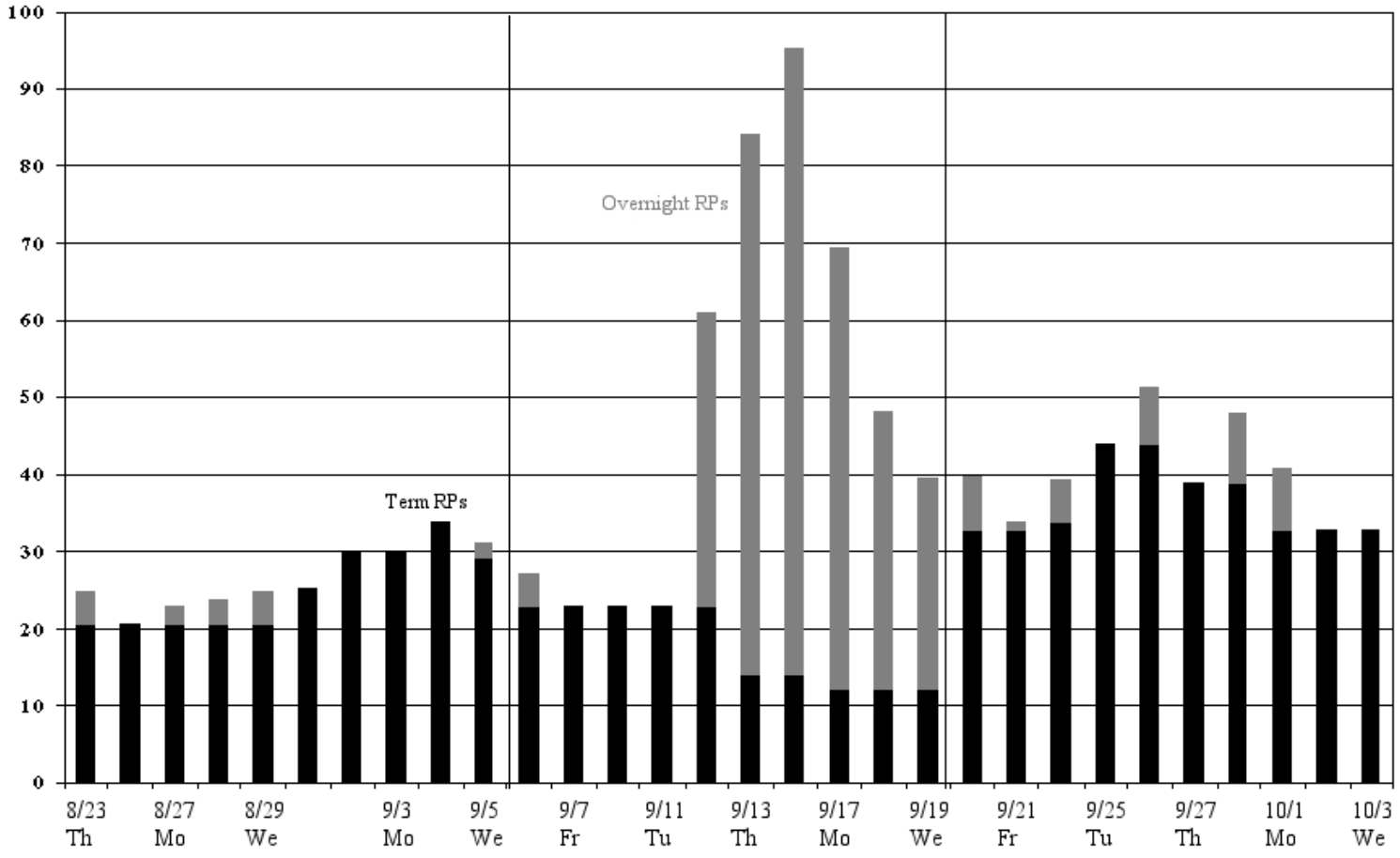


Contrarily to what Bagehot would have advised, however, the Fed did not provide liquidity at a high rate: "[The Desk] had to accept the vast majority of propositions-even those offered at rates well below the new 3 percent target level-in order to arrange RPs of sufficient size." 10

The consequences of providing such large amounts of liquidity can be seen in Chart 3 . The federal funds rate reached lows of zero on September 14, 17, and 18. The effective rate (a volume-weighted average of rates on trades arranged through the major brokers) was well below the target rate from September 17 to September 20 .

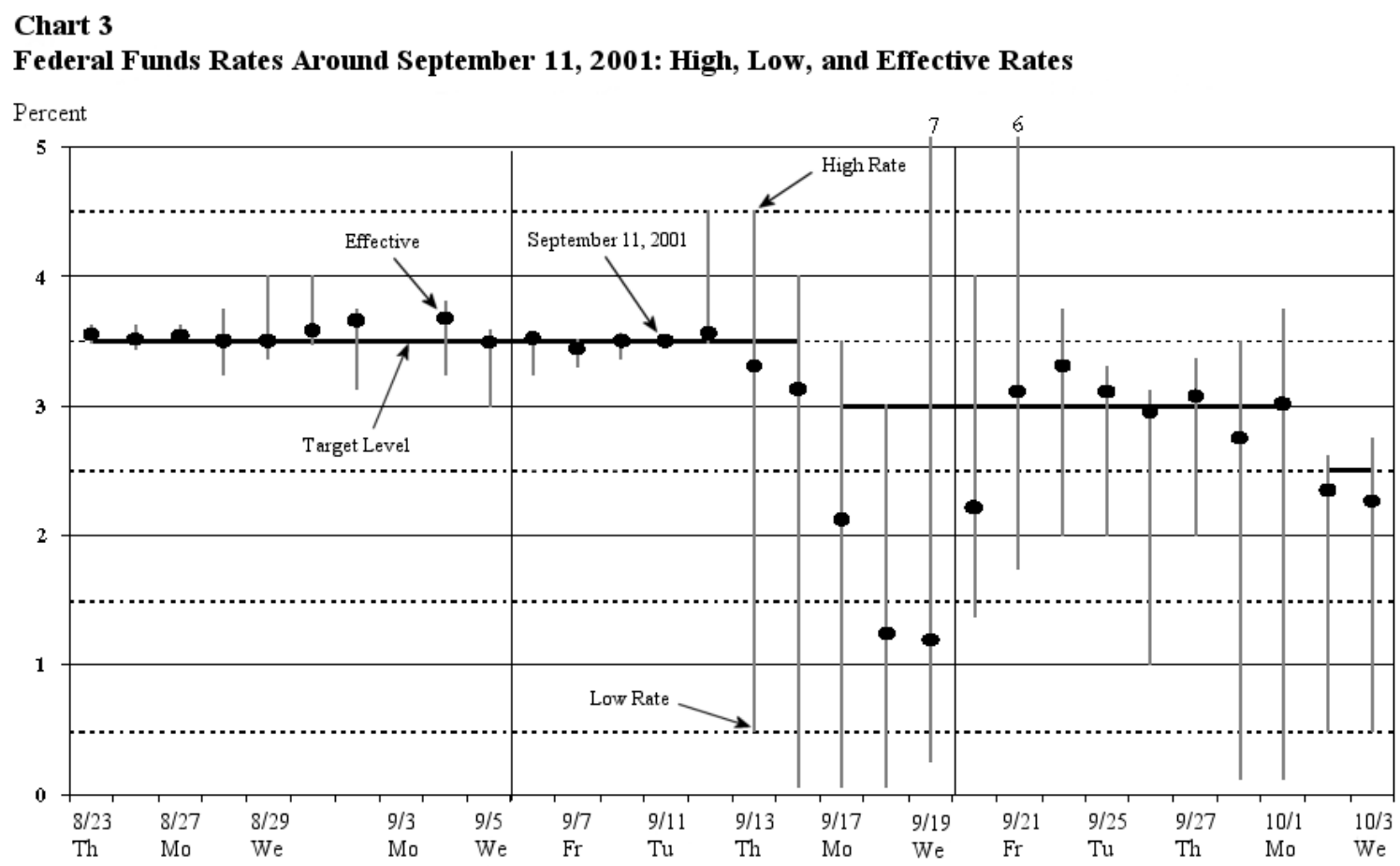

It is interesting at this point to take a closer look at the key assumptions behind the results of this paper. First, concerning the marginal cost of increasing the money supply, this paper follows a large literature in setting that cost to zero for fiat money. For commodity money, it might seem that this cost must approach infinity in the short run as some time is required for the CB to increase its reserves of gold. However, the Bank of England had the ability to expend its issue of notes and suspend their convertibility. The analysis remains valid if the cost of suspension of convertibility (real or perceived) is high enough. There is some evidence that this cost was indeed high; for example the panics of 1847 and 1857 subsided only after the Chancellor of the Exchequer announced it would cover the cost of the Bank of England if its Issue Department expanded its note issue without gold backing and was sued.

\footnotetext{
${ }^{10}$ Markets Group of the Federal Reserve Bank of New York (2000), page 24.
} 
Another assumption is that bank panics arise from a liquidity shortage. The observation that panics in XIX century England and the problems faced by banks in the days following September 11 both originate in a lack of liquidity greatly facilitates the analysis in this paper. Indeed, a single model that emphasizes this liquidity problem can be used to study both types of events. In the case of XIX century English banks, the liquidity shortage arises because of unusually large withdrawals from pessimistic depositors. Bagehot notes, “... in a panic there is no new money to be had; everybody who has it clings to it, and will not part with it." 11 After September 11, the breakdown of the interbank market is responsible for the liquidity shortage experienced by certain banks (see McAndrews and Potter (2002)).

Liquidity shortages in this paper are modeled as in Diamond and Dybvig (1983). This approach has been widely used to study bank panics of the type Bagehot talks about. It has also been applied to modern interbank markets (see Rochet and Vives (2002)) and thus seems particularly appropriate to the comparison between Bagehot's recommended policy and the Fed's response to the events of September 11, 2001.

The last key assumption mentioned in the introduction is that bank panics are contagious. This has long been believed to be true, and Bagehot clearly shares that view as he write, "In wild periods of alarm, one failure makes many, and the best way to prevent the derivative failure is to arrest the primary failure which caused them." ${ }^{12}$ Contagion seems to have been a concern following the events of September 11 as well. Given the heightened amount of uncertainty it is not hard to imagine that the problems of a few banks could have propagated to other banks. In any case, the analysis in this paper only requires that panics in a commodity money regime be contagious.

\section{The environment}

The model is adapted from Martin (2001) so as to allow the study of both a commodity money and a fiat money regime. Panics are modeled as in Diamond and Dybvig (1983) as indicated in the previous section. Also, as in Bryant and Wallace (1980), banks must satisfy a reserve requirement, to guarantee that fiat money is valued.

I make a "small open economy" assumption, so that the price of goods in terms of money

\footnotetext{
${ }^{11}$ Page 191.

${ }^{12}$ Page 53.
} 
is exogenously specified. This approach facilitates the comparison between the commodity money and the fiat money regime, as the equations of the model are the same in both cases. Only their interpretation is somewhat different. ${ }^{13}$

There is a continuum of households and of banks, each of mass 1, which live forever. There is one type of good at each date, denoted by $c$. Each date $t=0,1,2, \ldots$ contains four subperiods: $j=0,1,2,3$.

\subsection{Endowments}

Each household has an endowment of money $M$ at date 0 . Also, at every date, every household is endowed with an amount $\omega$ of the economy's single consumption good in subperiod 0 . No endowment is received in the other subperiods. Banks do not receive an endowment. The price of goods in terms of money is $p$, and it is assumed that, at the beginning of every date, there is a world market where goods can be exchanged for money and money can be exchanged for goods at that price. In other words, I assume that the banking system is too small to have an impact on the world price of money.

\subsection{Technologies}

There are two investment technologies. There is a short-term (storage) technology which yields one unit of the consumption good in subperiod $j$ for each unit invested in subperiod $j-1, j=1,2$. There is also a long-term technology which yields $R>1$ units of the consumption good in subperiod 2 for each unit invested in subperiod 0. Liquidating the long-term technology in subperiod 1 carries a cost in terms of good and returns only $r<1$. There is no technology that allows goods to be transferred from one date to the next. Hence the number of goods available at each date is always the same.

\footnotetext{
${ }^{13}$ It is possible to endogenize the price of the commodity money (in terms of goods) by introducing money into the utility function as in Velde and Weber (2000). Martin (2001) describes a similar model where the price of fiat money (in terms of goods) is endogenous. Doing so would make the comparison between the two regimes more difficult, without providing any additional insight.
} 


\subsection{Preferences}

As is usual in this kind of model, households can be of two types: patient or impatient. The impatient type only derives utility from consumption in subperiod 1, and the patient type derives utility only from consumption in subperiod 2. Types are learned at the beginning of subperiod 1 and are private information. Each household has a probability $\theta>0$ of being impatient, and it is assumed that a law of large number holds so that the proportion of impatient households in the population is $\theta$. Let $c_{j}$ denote the amount of the consumption good consumed in subperiod $j$. A household's expected utility in every period is:

$$
U\left(c_{1}, c_{2}, \theta\right)=\theta u\left(c_{1}\right)+(1-\theta) u\left(c_{2}\right) .
$$

The period utility function $u$ exhibits CRRA:

$$
u(c)=\frac{c^{1-\sigma}}{1-\sigma}, \quad \sigma>1 .
$$

\subsection{Reserve requirement}

To ensure that money is valued in the fiat money regime, banks are assumed to be subject to a reserve requirement as in Bryant and Wallace (1980). Specifically, banks must hold a fraction $\alpha \in(0,1)$ of their deposits in cash. While this requirement is not necessary for money to be valued in the commodity money regime, it is imposed in that version of the model as well, so the two regimes are comparable. ${ }^{14}$

\subsection{Sunspot}

With probability $\mu$ a sunspot appears. When it does, the depositors of a fraction $z \in[0,1]$ of banks have the belief that all other depositors in their bank will claim to be impatient. These banks are "panic-prone" and depositors will run these banks unless, as will be seen below, the banks can borrow some liquidity.

\footnotetext{
${ }^{14}$ This assumption is chosen for its convenience and not for its historical accuracy. There are other ways to make fiat money valued. For example, Martin (2001) imposes a cash-in-advance constraint. The interpretation of such a constraint in the commodity money regime is that some transactions cannot be performed with bank deposits.
} 
Depositors in the other banks believe that all other depositors will declare their true type, unless they observe that some panic-prone bank experiences a run. In that event, they also believe all other depositors will claim to be impatient. These banks are "non-panic-prone".

As is usual in this type of model, a bank experiences a run if patient depositors believe that all other depositors will claim to be impatient. This is because, if the belief is verified, the bank will need to liquidate the long-term technology, and there will be no goods left in subperiod 2. In addition to this standard effect, the pattern of beliefs described above implies that there can be contagion from panic-prone banks to non-panic-prone banks. ${ }^{15}$

A bank's type-panic-prone or not-is known only to the bank and its depositors. The fraction $z$ of panic-prone banks is unobservable and random. It is distributed according to a c.d.f. denoted by $F$. The associated p.d.f., $f$, is assumed to have the property that $f(z)>0$, all $z \in[0,1]$, and $f(z) \rightarrow 0$ as $z \rightarrow 1$. Since $z$ can be thought of as the severity of a panic, this condition can be interpreted as saying the probability of a panic of a given severity goes to zero as panics become extremely severe. In other words, extremely severe panics are vanishingly rare.

\subsection{Timing}

The timing of events is represented graphically below. The abbreviation HHs is used to denote households.

In subperiod 0, households deposit their endowment of good and cash at the bank and obtain deposit contracts. Banks, in turn, choose how to invest those goods in the short-term and the long-term technology. At the beginning of subperiod 1, households privately learn their type and observe, together with banks, if a sunspot appears. After that, households can choose to go to the bank and withdraw their deposits. An household liquidating its deposits receives either cash or claims on goods-or both-from the bank. These claims are a liability of the bank. Thus, each bank must sell enough goods to redeem those claims. ${ }^{16}$ It is assumed that banks sell the product of their investments on a competitive market. Both cash and claims on goods obtained at a bank can be used to purchase goods on that market. In

\footnotetext{
${ }^{15}$ The main advantage of introducing contagion in this way is tractability. Contagion could be modeled more rigorously along the lines of Chen (1999).

${ }^{16}$ One can think of the claims as being redeemed directly at the issuing bank. Equivalently, each bank accepts claims issued by other banks and the claims are cleared between banks at the end of the sub-period.
} 
subperiod 2, households who claim to be impatient withdraw. Again, they can obtain goods from a competitive market with cash or claims on goods. During subperiod 3, households obtain the cash held by banks. At the end of subperiod 2, banks hold cash from the sale of goods. However, they have no more use for it since all deposits have been withdrawn. Households acquire this money in anticipation of the next period.

\section{Timing}

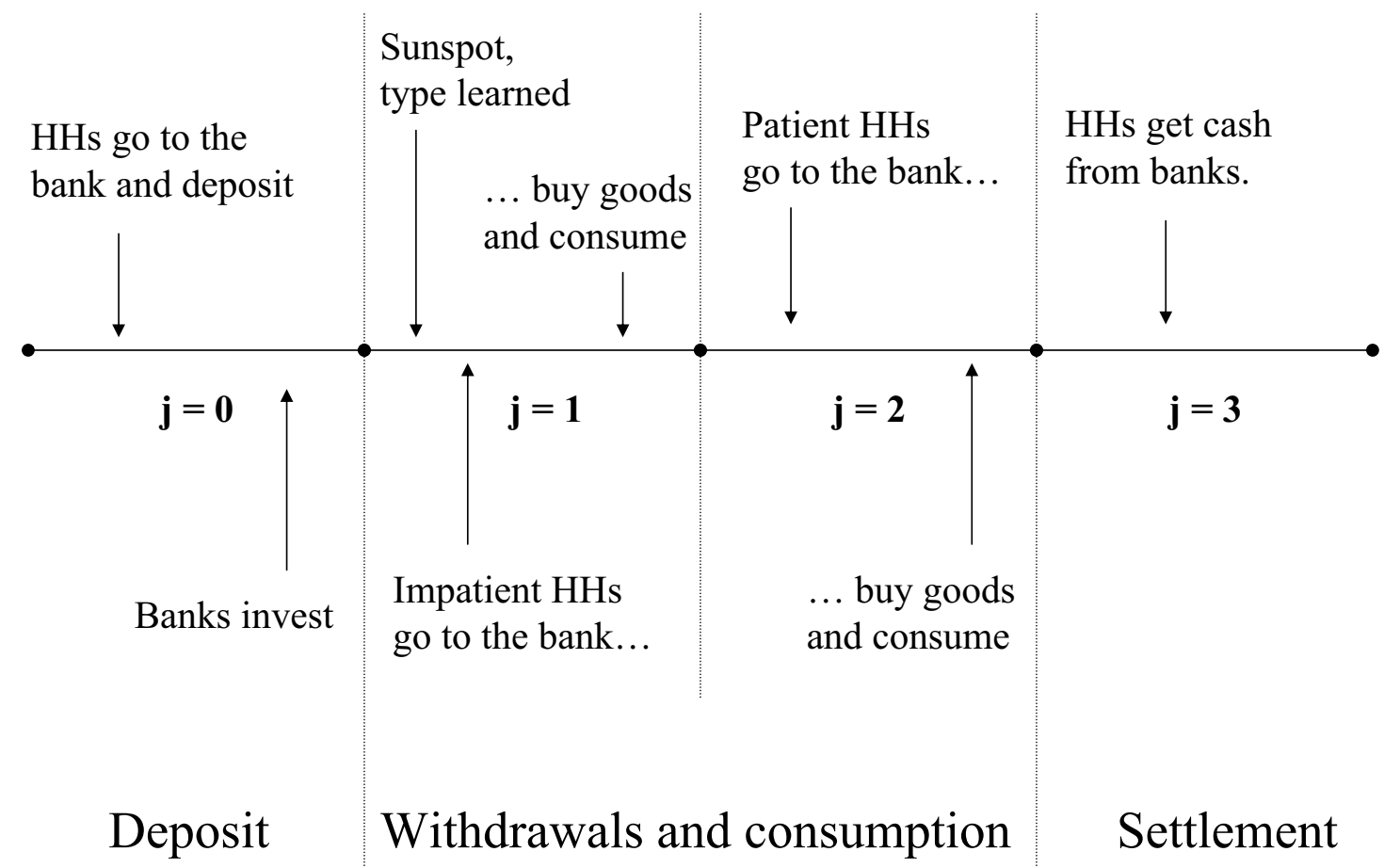

\subsection{Contracts}

Contracts offered by banks may not depend on the sunspot de jure. However, because of the sequential-service constraint, bank contracts de facto depend on the sunspot since a bank runs out of resources during a panic. All contracts are written in subperiod 0 in nominal terms. Banks, by assumption, can give withdrawing depositors either cash or nominal claims on goods, or both. Either can be used in the goods market.

Definition 3.1. A contract is a triple $\left(x_{1}, x_{2}, x_{3}\right) \in R_{+}^{3}$, where $x_{i}$ denotes the number of 
dollars paid in subperiod $i \in\{1,2,3\}$.

Households may not resell their contracts in subperiod 1. As was first pointed out by Jacklin (1987), without this assumption banks are redundant.

Without loss of generality, attention in what follows can be limited to two contracts between the households and the banks. ${ }^{17}$ First the Deposit contract takes the form $(1, \lambda, 0)$, with $\lambda \geq 1$. Each deposit contract allows households to obtain either $\$ 1$ in subperiod 1 , or $\$ \lambda$ in subperiod 2 (but not both). $\lambda$ can be thought of as the interest rate paid by the banks. Second, the Cash-for-next-period contract: takes the form $(0,0,1)$. Cash-for-next-period contracts allow households to obtain $\$ 1$ in subperiod 3. Since no consumption takes place in this subperiod, households save this cash until the next date.

\subsection{The household's problem}

A household chooses how much to deposit in the banks and which type (patient or impatient) to announce in order to maximize its utility. For simplicity, only the case where households deposit all their assets (goods and money) in banks is considered. ${ }^{18}$

Impatient households always report their type truthfully, since consuming in subperiod 2 has no value to them. Patient households, on the other hand, announce their true type if they believe all other households will. They claim to be impatient if they think all households will do so as well, and obtain goods that will be saved until the next subperiod using the short-term technology. The event of all households claiming to be impatient is associated with a bank panic.

In case of panic, there will not be enough resources for all households to consume in subperiod 1. Let $\eta$ denote the fraction of households that arrive at their bank before its resources are exhausted. All households are assumed to have an equal probability of arriving at their bank in time.

Given the households utility function, the fraction $1-\eta$ of households that arrive at their bank after it has exhausted its resources have infinite disutility. To make sure households will deposit all their assets in banks, depositors who arrive at their banks late are assumed

\footnotetext{
${ }^{17}$ This is proved formally in the appendix.

${ }^{18}$ If there were no panics, households would always choose to invest all their assets in banks as they provide insurance against the risk of being impatient.
} 
to receive some utility $\underline{u} \leq u\left(c_{1}\right) .{ }^{19}$

Let $c_{1}$ and $c_{2}$ denote the consumption of households who claim to be impatient and patient, respectively, when there is no sunspot. A household's budget constraint is

$$
q_{1} W_{1}+q_{M^{\prime}} W_{M^{\prime}} \leq p \omega+M
$$

where $W_{1}, W_{M^{\prime}}$ are the quantities of deposit contracts and cash-for-next-period contracts, respectively, that the household buys at prices $q_{1}$ and $q_{M^{\prime}} . M$ is the amount of money held by the household. The amount of contracts a household has limits the value of the goods it can buy:

$$
\begin{aligned}
p c_{1} & \leq W_{1} \\
p c_{2} & \leq \lambda W_{1} \\
M^{\prime} & \leq W_{M^{\prime}}
\end{aligned}
$$

Combining these constraints (which hold at equality), one can see that the household solves the following dynamic problem:

$v\left(\frac{M}{p}\right)=\max \quad(1-\mu)\left[\theta u\left(c_{1}\right)+(1-\theta) u\left(c_{2}\right)\right]+\mu\left[\eta u\left(c_{1}\right)+(1-\eta) \underline{u}\right]+\beta v\left(\frac{M^{\prime}}{p^{\prime}}\right)$,

subject to

$$
\begin{aligned}
q_{1} p c_{1}+q_{M^{\prime}} M^{\prime} & \leq p \omega+M \\
c_{2} & =\lambda c_{1} \\
0 & \leq M^{\prime}, c_{1}, c_{2} .
\end{aligned}
$$

The first constraint is the budget constraint. The second constraint says that households that claim to be patient receive at least as much consumption as households that claim to be impatient. From the first order conditions and the envelope condition, one gets

$$
\begin{aligned}
\frac{1}{p} v^{\prime}\left(\frac{M}{p}\right) q_{1} & =[(1-\mu) \theta+\mu \eta] \frac{u^{\prime}\left(c_{1}\right)}{p}+\lambda(1-\mu)(1-\theta) \frac{u^{\prime}\left(c_{2}\right)}{p}, \\
\frac{1}{p} q_{M^{\prime}} v^{\prime}\left(\frac{M}{p}\right) & =\frac{1}{p^{\prime}} \beta v^{\prime}\left(\frac{M^{\prime}}{p^{\prime}}\right) .
\end{aligned}
$$

\footnotetext{
${ }^{19}$ For every $\underline{u}>0$, there is a $\mu$ sufficiently small that households prefer to deposit all their assets in banks. $\underline{u}$ can be interpreted as a government transfer. Another interpretation is that all households can obtain some goods if they work. Working causes some fixed utility cost sufficiently high that a household will not work if it can withdraw from the bank
} 
Only stationary equilibrium with a constant money supply are considered. $M=M^{\prime}$ and $p=p^{\prime}$ imply, together with the last condition, that $q_{M^{\prime}}=\beta$.

\subsection{The bank's problem}

With $M_{1}$ and $M_{2}$ denoting the amount of money the bank sets aside to satisfy its reserve requirement against the deposits of impatient and patient households, respectively, $M=$ $M_{1}+M_{2}$. A bank chooses the number of contracts it sells to households $\left(W_{1}\right.$ and $\left.W_{M^{\prime}}\right)$, the amount of money and goods it obtains from households ( $M$ and $\omega$, respectively), how much to invest in both the short-term and the long-term technologies ( $i_{1}$ and $i_{2}$, respectively), and how much money to set aside for its reserve requirement $\left(M_{1}\right.$ and $\left.M_{2}\right)$ in order to maximize its profits. Since banks are perfectly competitive they make zero profit in equilibrium. Also, the contract they offer will, in equilibrium, maximize the expected utility of the households. The bank's problem is

$$
\max \quad q_{1} W_{1}+q_{M^{\prime}} W_{M^{\prime}}-p \omega-M
$$

subject to

$$
\begin{aligned}
i_{1}+i_{2} & \leq \omega, \\
\theta W_{1} & \leq p i_{1}, \\
\lambda(1-\theta) W_{1} & \leq p R i_{2}, \\
\alpha \theta W_{1} & \leq M_{1}, \\
\lambda \alpha(1-\theta) W_{1} & \leq M_{2}, \\
M_{1}+M_{2} & \leq M, \\
W_{M^{\prime}} & \leq M, \\
0 & \leq W_{1}, W_{M^{\prime}}, M, M_{1}, M_{2}, \omega, i_{1}, i_{2} .
\end{aligned}
$$

The first constraint is a resource constraint. It states that the total amount of the good invested cannot exceed the goods acquired from the households. ${ }^{20}$ The second and third constraints state that the value of the goods owed to households can be no greater than the value of the goods the bank will sell. The fourth and fifth constraints are the reserve

\footnotetext{
${ }^{20} \mathrm{It}$ is assumed that banks cannot accept deposits from abroad. All banks end up investing $\omega$ by symmetry.
} 
requirement constraints. The sixth constraint states that the amount of cash set aside to satisfy the reserve requirement can be no greater than the total amount of cash available to the bank. Finally, the seventh constraint says that the amount of cash the bank must give households at the end of the period is no greater than the amount of cash it has.

It is assumed that $\mu$ is sufficiently small so the reserve requirement constraints are binding. In other words, banks do not hold excess reserves. ${ }^{21} \mathrm{~A}$ consequence of this assumption is that banks cannot lend to each other and have to rely on the CB for additional liquidity. ${ }^{22}$ The main results of the paper will be shown to be unaffected if banks do lend to each other.

The condition for an interior solution to the bank's problem is,

$$
q_{1}=\left[\theta+\frac{\lambda}{R}(1-\theta)\right]+(1-\beta) \alpha[\theta+\lambda(1-\theta)] .
$$

The fraction $\eta$ of households that arrive at the bank after its resources are exhausted is given by

$$
\eta=\frac{i_{1}}{i_{1}(1-r)+r \omega}
$$

so that $\eta \rightarrow 0$ as $i_{1} \rightarrow 0$, and $\eta \rightarrow 1$ as $i_{1} \rightarrow \omega$.

When there is no panic, it does not matter how banks distribute the cash and claims on goods to withdrawing depositors. However, in the case of a panic it can matter. The reason is that while a bank must always be able to exchange goods for a claim it issued, it does not have an obligation to exchange goods for cash. Hence, as is shown in the lemma below, a bank might be able to prevent panics if it holds enough cash.

In case of panic, assume the first $\theta$ households receive the same shares of cash and claims as they would if there were no panic. Households arriving after $\eta$ receive nothing. Finally, assume households arriving between $\theta$ and $\eta$ all receive the same share of cash and claims. ${ }^{23}$ Also, assume that households arrive at the market in the same order they arrived at the bank.

Lemma 3.2. If $M_{2} /(1-\theta) \geq p i_{1} / \theta$, bank panics will not occur.

Proof. Under the above hypothesis, $M_{2} /(1-\theta)$, the amount of cash the bank has set aside for patient households, is bigger than $p_{n} c_{1} / \theta$, the amount the bank must pay households which claim to be impatient. Thus the bank can pay patient households claiming to be impatient

\footnotetext{
${ }^{21}$ As $\mu$ tends to zero the benefit from holding an extra unit of money vanishes, while the cost is constant.

${ }^{22}$ Battacharya and Gale (1987) study an environment in which banks lend to each other.

${ }^{23}$ Note that this share must be different from the share received by the first $\theta$ households.
} 
without having to liquidate the long-term technology. But this in turn implies that patient households are strictly better off revealing their true type.

Lemma 3.3. If $\alpha<1 / R$, then $M_{2} /(1-\theta)<p i_{1} / \theta$.

Proof. First, note that $\lambda \leq R$ (it is easy to show that if this were not the case, impatient depositors would get less than the return on the short term technology). Hence, $\lambda \alpha \leq R \alpha<1$. It follows that $p i_{1} / \theta=W_{1}>\lambda \alpha W_{1}=M_{2} /(1-\theta)$, where the last equality holds because the fifth constraint of the bank's problem is holding at equality.

Since the interesting case is when bank panics occur, it is assumed that $\alpha<1 / R$.

Two comments are in order. First, if there were a liquid market for the banks' assets, banks would be able to acquire enough cash to prevent panics. Indeed, banks in this model are solvent but illiquid. Banks here are unable to buy each others assets but, potentially, sellers on the world market could. The fact that this market does not function can be motivated by informational asymmetries (see Rochet and Vives (2002) and some references therein). Also, one could assume that (foreign) sellers on the world market are unable to get their claims enforced in domestic courts. In the next section it will be shown that the CB can prevent panics by repurchasing the banks' assets. Second, because households receive cash and goods in the pattern described above, and because they reach the market in the same order they reach the bank, panics will occur if the condition in the lemma is not met. Indeed, any additional claims issued by a bank would be redeemed and the bank would have to liquidate the long term technology. ${ }^{24}$

\section{Equilibrium and the efficient allocation}

This section defines an equilibrium when there is no CB intervention. Policies will be considered that aim at preventing bank runs. Only stationary equilibria are considered.

Definition 4.1. Given $\omega, M, r, R, \mu$, a stationary equilibrium is a set of prices

$$
\left\{q_{1}, q_{M^{\prime}}, p, p^{\prime}, \lambda\right\}
$$

\footnotetext{
${ }^{24}$ The results obtained in the two lemmas would hold, with slight modifications, if banks paid the withdrawing depositors in a different way; for example, if the bank gave only claims to the depositors that arrive first, and then only cash to the subsequent ones.
} 
and an allocation

$$
\left\{W_{1}, W_{M^{\prime}}, M_{1}, M_{2}, M^{\prime}, c_{1}, c_{2}, i_{1}, i_{2}\right\}
$$

such that:

1) Given prices, the allocation solves the problem of the households, the banks and the firms.

2) Markets clear

$$
\begin{aligned}
\theta c_{1} & =i_{1}, \\
(1-\theta) c_{2} & =R i_{2}, \\
M & =M^{\prime} .
\end{aligned}
$$

The equilibrium can be characterized from the following equations:

$$
\begin{aligned}
q_{1} & =\left[\theta+\frac{\lambda}{R}(1-\theta)\right]+(1-\beta) \alpha[\theta+\lambda(1-\theta)], \\
c_{2} & =\lambda c_{1}, \\
v^{\prime}\left(\frac{M}{p}\right) q_{1} & =[(1-\mu) \theta+\mu \eta] u^{\prime}\left(c_{1}\right)+\lambda(1-\mu)(1-\theta) u^{\prime}\left(c_{2}\right), \\
q_{1} p c_{1} & =(1-\beta) M+p \omega .
\end{aligned}
$$

Since $\theta c_{1}=i_{1}$ and $(1-\theta) c_{2}=R\left(\omega-i_{1}\right)$, there are five unknowns- $M, q_{1}, i_{1}, v^{\prime}\left(\frac{M}{p}\right), \lambda$-and four equations. However, another equation can be obtained since, in equilibrium, $\lambda$ be such that the household's utility is maximized. The proof of the existence of an equilibrium with bank panics for small values of $\alpha$ and $\mu$ is given in the appendix.

The efficient allocation is the allocation obtained by a planner who can observe whether households are patient or impatient. It solves

$$
\max \theta u\left(c_{1}\right)+(1-\theta) u\left(c_{2}\right)
$$

subject to

$$
\begin{aligned}
\theta c_{1} & \leq i_{1} \\
(1-\theta) c_{2} & \leq R i_{2}, \\
i_{1}+i_{2} & \leq \omega \\
c_{1}, c_{2}, i_{1}, i_{2} & \geq 0 .
\end{aligned}
$$


The solution to this problem is characterized by

$$
\begin{aligned}
u^{\prime}\left(c_{1}\right) & =R u^{\prime}\left(c_{2}\right), \\
\theta c_{1}+\frac{(1-\theta) c_{2}}{R} & =\omega .
\end{aligned}
$$

It can be shown (see Martin (2001)) that the equilibrium allocation is efficient if $\mu=0$. If $\mu>0$, the equilibrium allocation will not be efficient, unless a policy is put in place that makes telling the truth a best response for households (assuming that the policy itself does not introduce inefficiencies).

\section{Liquidity provision in a fiat money regime}

The key element that makes crises in the model resemble the problems faced by banks after September 11 is that they arise from a liquidity shortage. Banks that had high liquidity needs can be associated with panic-prone banks. A CB can help these banks by providing them with liquidity.

In a fiat money regime, the $\mathrm{CB}$ has the ability to issue fiat money at no cost and organize repurchase agreements with banks. The CB is not allowed to purchase goods from the market with the money it issues.

A liquidity provision policy taking the form of a repurchase agreement gives households the incentive to reveal their true type. ${ }^{25}$ Formally, the CB posts prices at which it is willing to buy claims on goods invested in the long term technology in subperiod 1, and sell these same claims back in subperiod 2. The ratio of these prices is the interest rate at which the CB lends reserves. The timing of the policy is as follows: At the beginning of subperiod 1, banks and households observe the sunspot, but the CB does not. Then, each bank decides if it wants to sell assets to the CB. At the beginning of subperiod 2, banks who sold assets to the CB buy them back and pay patient depositors.

It can be shown that this policy prevents bank panics and achieves the efficient allocation if the CB lends reserves at a zero interest rate. Panics are prevented because the extra liquidity allows the bank to pay all withdrawing depositors without having to liquidate the long-term technology. Thus, patient households prefer to withdraw in subperiod 2, no matter what they

\footnotetext{
${ }^{25}$ Note that in this environment, a repurchase agreement is equivalent to a discount window loan. See Freeman (1999) for en environment in which these two policies have different effects.
} 
believe about other households' actions. Charging a positive interest rate lowers the expected utility of households. This is because depositors in panic-prone banks will consume less than those in non-panic-prone banks, and this uncertainty is disliked by risk averse households.

This policy is similar to what the Federal Reserve did in the days following September 11, 2001. It is consistent with the second part of Bagehot's recommendation, that loans be made "as largely as the public asks for them," but it is not consistent with the first, that funds be lent at a "very high interest rate." The Fed did not restrict access to liquidity, or try to ration the amount of liquidity it lent through high prices. ${ }^{26}$

\section{Liquidity provision in a commodity money regime}

This section shows that in a commodity money regime lending at a zero interest rate cannot prevent bank runs because the $\mathrm{CB}$ cannot increase its liquidity without limits the way it could in a fiat money regime. In this section it is assumed, for simplicity, that the quantity of bank reserves is fixed, so that the marginal cost of increasing the money supply is infinite. As noted above, the analysis remains valid if this cost is finite but sufficiently high. ${ }^{27}$ However, Bagehot policy can prevent some bank panics.

The CB holds some fixed amount of commodity money and is allowed to provide liquidity to banks through repurchase agreements. The CB is not allowed to purchase goods directly from the market. In this section it is assumed that the CB does not hold enough reserves to prevent all panics.

The repurchase policy considered here is the same as in the fiat money case. The CB sets the prices at which it buys and sells the assets, implicitly determining an interest rate, which will be denoted by $i^{C B}$.

A bank that is threatened by a run needs to obtain an amount $\hat{M} \equiv p_{n} c_{1} \frac{1-\theta}{\theta}-M_{2}$ from the CB (See Martin (2001)). By assumption, $\hat{M}>0$. Let $\varphi \hat{M}$, with $\varphi<1$, denote the

\footnotetext{
${ }^{26}$ However, while the optimal policy calls for a rate of interest of zero, the effective Federal Funds Rate only declined to near 1 percent. This is partly due to the fact that the Fed did not announce it would accept bids at any rate of interest. Maintaining such "constructive ambiguity," as well as the ability to reject some bids, might be a way for the Fed to reduce the risk of moral hazard.

${ }^{27}$ There are some similarities between the CB in this section and the "asset trader" in Allen and Gale (1999). However, since they do not consider contagious panics, there is no scope for self-selection of banks in their model.
} 
amount of reserves held by the CB. If the fraction of panic-prone banks $z$ is bigger than $\varphi$, then some panic-prone bank will experience a run. The assumption that this happens with positive probability can be written $1-F(\varphi)>0$.

The $\mathrm{CB}$ is subjected to a sequential-service constraint: it gives an amount of liquidity $\hat{M}$ to all banks that ask for it until it runs out of reserves. Lending less than $\hat{M}$ would not protect banks from a panic, while lending more would be a waste of scarce funds. Each bank has an equal probability of obtaining reserves from the CB.

Proposition 6.1. If $i^{C B}=0$, then each sunspot leads to bank panics.

Proof. If $i^{C B}=0$, all banks want to borrow funds from the CB. Clearly panic-prone banks want to borrow, but even non-panic-prone banks have an incentive to do so. Indeed, since $1-F(\varphi)>0$, there is a positive probability that the CB's reserves are not sufficient to service all panic-prone banks, even if only panic-prone banks ask for liquidity. Moreover, since $z$ is unobservable it is not possible to tell when such a case happens. Since all banks borrow and all banks have the same probability of getting funds from the $\mathrm{CB}$, then for all $z>0$ there must be some panic-prone bank that does not get funds. This triggers runs on all non-panic-prone banks that were unable to borrow.

This proposition shows that a panic will occur even if $z<\varphi$, despite the fact that the CB has enough reserves to prevent a panic if it can make sure only panic-prone banks obtained the reserves. By assumption, whether a bank is panic-prone or not is private information and thus the CB cannot choose to give the reserves only to panic-prone banks.

Of course, if $z$ were observable then it would be optimal for the CB to set $i^{C B}=0$ whenever $z<\varphi$. In that case, non-panic-prone banks would know they need not borrow, since there are enough reserves for all the panic-prone banks. Clearly, if $\varphi<z$, panics cannot be prevented.

Since $z$ is unobservable, the CB needs an incentive-compatible way of finding out which banks are panic-prone and which ones are not. The next proposition shows that the CB needs to set the interest rate at which it lends high enough.

Proposition 6.2. There exists $i^{C B}$ high enough such that it is a Nash equilibrium for panicprone banks to borrow and for non-panic-prone banks not to borrow from the CB.

Proof. Recall that because of perfect competition between banks, they maximize the expected utility of their depositors. Any bank that borrows $\hat{M}$ from the central bank will avoid a run. Let $u_{n r}$ denote the utility of the depositors in banks that borrow from the CB. Panic-prone 
banks that do not borrow will experience a run with probability 1 . Let $u_{w}$ denote the expected utility of depositors in such banks. If non-panic-prone banks do not borrow and panic-prone banks do, then non-panic-prone banks will experience a run with probability $F(\varphi)<1$. Let $u_{s}$ denote the expected utility of these banks' depositors. Clearly, $u_{s}>u_{w}$. I need to show that there exists $i^{C B}$, such that $u_{s}>u_{n r}>u_{w}$, for in that case panic-prone banks would always want to borrow when a sunspot appears and non-panic-prone banks would not. From proposition 6.1 , if $i^{C B}=0$, then $u_{n r}>u_{s}$. Taking other banks' behavior as given, the level of the interest rate does not affect the utility of depositors in banks that do not borrow. Thus, $u_{s}$ and $u_{w}$ are not affected by $i^{C B}$. Clearly, $u_{n r}$ decreases continuously as $i^{C B}$ increases and $\lim _{i C B \rightarrow \infty} u_{n r}=-\infty$. This completes the proof.

In order to prevent bank panics, the CB must make sure that only panic-prone banks will ask for liquidity. An incentive compatible way for the CB to find out which banks are panic-prone is to offer liquidity at a high interest rate. ${ }^{28}$ The above proposition shows that there exists an interest rate at which panic-prone banks will borrow from the $\mathrm{CB}$, while nonpanic-prone banks will not if they believe that panic-prone banks borrow. Under this policy, a panic will occur with probability $1-F(\varphi)>0$ whenever a sunspot occurs, while if $i^{C B}=0$, then a panic occurs with probability 1 .

Goodhart (1999) argues that some authors have claimed, mistakenly, that the high interest rate of Bagehot's policy is a penalty rate. Proposition 6.2 supports Goodhart's point as the high interest rate is not a penalty. It is a self-selection device. Indeed, the CB should choose the lowest rate consistent with self-selection.

Bagehot's policy does not implement the efficient allocation for at least two reasons. First, it does not prevent all panics. Second, when it does, the positive interest rate penalizes depositors at panic-prone banks. However, it is the best policy in the class considered.

This exercise does not allow the determination of the best possible policy in a commodity money regime. What it shows is that the Fed's policy after September 11 is better than Bagehot's in a fiat money regime (indeed no other policy can do better), while Bagehot's policy is better than the Fed's in a commodity money regime.

\footnotetext{
${ }^{28}$ Since the CB charges a positive interest rate, its reserves increase whenever it lends. To maintain the CB's reserves at a constant level, assume that excess reserves are redistributed through lump-sum payments to households.
} 


\section{The optimal quantity of central bank reserves}

In a commodity money regime, in contrast to a fiat money regime, the amount of reserves that the CB holds directly affects the households' of consumption. By reducing its reserves by one unit, the $\mathrm{CB}$ can obtain $p$ units of goods, which can be consumed or invested by the banks.

This section considers the choice of reserves made by a $\mathrm{CB}$ that tries to maximize the utility of households. The basic trade-off is between a reduction in the goods available for consumption, which reduces expected utility, and a decrease of the probability of a panic, which increases expected utility. Given the assumption that the probability of severe panics tend to zero as they become more severe, the CB chooses reserves so that the probability of a panic is strictly positive.

Suppose the charter of the CB specifies the resources at its disposal, together with the way these funds must be used (i.e., the policy described in the previous section). The funds can be obtained from the households directly or indirectly through a government, which has the ability to impose lump-sum taxes. Since all households are ex-ante identical they agree to set up the $\mathrm{CB}$ in that way if it increases their expected utility.

As in the previous section, let $\varphi \hat{M}, \varphi \in[0,1]$, denote the amount of CB reserves. For each value of $\varphi$, there are equilibrium values of $c_{1}, c_{2}$, and $M^{\prime}$, which imply a particular level of expected utility for the households. The objective of the $\mathrm{CB}$ is to find $\hat{\varphi} \in[0,1]$ that maximizes this expected utility.

Proposition 7.1. $\hat{\varphi}$ is such that $F(\hat{\varphi})<1$.

Proof. The idea of the proof is that the gain of eliminating panics completely cannot compensate the cost of reducing the amount of consumption of the households. Thus, there is always a positive probability of a panic.

Because of the assumption that $f(z) \rightarrow 0$ as $z \rightarrow 1$, the marginal expected utility gain to the households of an increase in $\varphi$ tends to zero. This is because the reduction in the probability of a panic brought about by each additional unit of reserves tends to zero. On the other hand, since increasing $\varphi$ reduces consumption, the marginal expected utility cost to the households of an increase in $\varphi$ is strictly positive and increasing, since marginal utility increases as consumption decreases. Thus, there exists $\bar{\varphi}$ such that $F(\bar{\varphi})<1$ and the marginal expected utility cost of that amount of reserves is higher than the marginal expected utility benefit. It must be the case that $\hat{\varphi}<\bar{\varphi}$, so the proof is complete. 
Although the CB could eliminate all panics, it chooses not to do so if extremely severe panics are very rare because it is too expensive in terms of resources. Note that this proposition does not depend on the fact that banks do not lend to each other. If they did, the CB would reduce the amount of reserves it holds until the probability of a panic becomes, once again, strictly positive.

\section{Conclusion}

This paper reconciles Bagehot's recommended policy of lending reserves at a high interest rate with the practice of the Federal Reserve after September 11, 2001, of lending funds at interest rates close to zero. ${ }^{29}$ The key is to recognize that Bagehot had in mind a commodity money world, while the Fed operates in a fiat money world. Using a version of the model in Martin (2001), the paper shows that in a fiat money regime, no policy can do better than lending funds at a zero interest rate. In particular, Bagehot's policy is strictly worse. On the other hand, in a commodity money regime, lending funds at a zero interest rate cannot prevent bank panics, while Bagehot's policy can. The reason for this result is that when reserves are scarce and panics are contagious, the CB should allocate the reserves to panic-prone banks rather than non-panic-prone banks. Charging a high interest rate on reserves allows banks to self select or, in other words, to credibly reveal their type.

The paper also shows that if extremely severe panics are vanishingly rare, a CB that tries to maximize the household's expected utility will choose a level of reserves such that panics happen with strictly positive probability. Increasing reserves has the benefit of reducing the probability of a panic, but in a commodity money world it also reduces the amount of goods available for consumption. If extreme panics are sufficiently rare, the cost of eliminating runs completely is too high compared to the lost consumption.

The economic point made in this paper is very general. It applies to any environment in which liquidity shortage can lead to a panic and panics can spread through contagion. In such environments, the optimal strategy when the marginal cost of additional liquidity is sufficiently low is to prevent all panics and set a low price for this liquidity. The equilibrium

\footnotetext{
${ }^{29}$ The model implies that the Fed could have done even better if it had lowered the interest rate on discount window loans. In 2002, the Fed modified the way in which the discount window operate. The interest rate is now set to be 100 basis point above the Federal Funds Rate target. However, it is specified that the interest rare can be lowered in special circumstances.
} 
allocation converges to the efficient allocation as the marginal cost goes to zero. If the marginal cost of additional liquidity is sufficiently high, it is preferable to induce economic agents to self-select. On way of doing this is by setting a high price for additional liquidity. Specifically, this logic should apply to model of international debt default or currency crisis. ${ }^{30}$ This type of model could yield important insights for the design of an institution aiming at preventing international debt crises.

\footnotetext{
${ }^{30}$ Lambertini (2001) studies liquidity provision policies in a model of international debt default.
} 


\section{Appendix}

\section{Generality of contracts}

I show that limiting myself to the contracts described in section 3.7 is without loss of generality. Note that the demand for cash by households in sub-period 3 is independent of the sunspot. Thus having the cash-for-next-period contracts not depend on the sunspot is without loss of generality.

Things are a little more complicated for the contracts that the bank offers the household, because the household type is private information. First it is shown that allowing contracts such as $(1,0,0)$, and $(0,1,0)$, cannot yield a better outcome. Assuming $\lambda \geq 1$ is without loss of generality, since it can never be optimal for patient household to consume less goods that impatient households. Suppose that a household wants to buy a positive quantity of both the contracts described above. This contradicts the fact that $\lambda$ must be such that the utility of households is maximized. Thus, only the cases where one of the above contract is bought, together with the deposit contract, need to be considered. Suppose a household buys both the deposit contracts and the contract $(0,1,0)$. This contract is worthless to the household if it is impatient, but it allows the household to purchase more goods if it is patient. An equivalent allocation could be obtained with deposit contract having a higher $\lambda$, so this contradicts the fact that $\lambda$ maximizes the utility of households. Finally, suppose a household buys both the deposit contracts and the contract $(1,0,0)$. The household will be able to obtain goods with this contracts. The goods will be consumed in sub-period one if the household is impatient, and stored until sub-period 2 if the household is patient. Again, this allocation could be obtained with a deposit contract having a lower $\lambda$, and this contradicts the fact that $\lambda$ maximizes the utility of households. This completes the proof.

\section{Existence of equilibrium}

I will show that an equilibrium with bank panics exists for small values of $\alpha$ and $\mu$. $\alpha$ must be small so that banks do not hold enough cash to prevent all bank panics. $\mu$ must be small so that households deposit all their assets in banks and banks hold no excess reserves. Under such conditions the equations characterizing an equilibrium are 


$$
\begin{aligned}
q_{1} & =\left[\theta+\frac{\lambda}{R}(1-\theta)\right]+(1-\beta) \alpha[\theta+\lambda(1-\theta)], \\
c_{2} & =\lambda c_{1}, \\
v^{\prime}\left(\frac{M}{p}\right) q_{1} & =[(1-\mu) \theta+\mu \eta] u^{\prime}\left(c_{1}\right)+\lambda(1-\mu)(1-\theta) u^{\prime}\left(c_{2}\right), \\
q_{1} p c_{1} & =(1-\beta) M+p \omega, \\
\theta c_{1} & =i_{1}, \\
(1-\theta) c_{2} & =R\left(\omega-i_{1}\right) .
\end{aligned}
$$

There are 7 unknowns, $M, q_{1}, i_{1}, v^{\prime}\left(\frac{M}{p}\right), \lambda, c_{1}$ and $c_{2}$. The seventh equation is given by the fact that the contract offered by the banks must, in equilibrium maximize the household's utility.

Hence, it must be the case that $i_{1}$ solves

$$
\max _{i_{1}}(1-\mu)\left[\theta u\left(\frac{i_{1}}{\theta}\right)+(1-\theta) u\left(\frac{R\left(\omega-i_{1}\right)}{1-\theta}\right)\right]+\mu\left[\eta\left(i_{1}\right) u\left(\frac{i_{1}}{\theta}\right)+\left(1-\eta\left(i_{1}\right)\right) \underline{u}\right]
$$

Since this is a continuous, strictly concave (for sufficiently small $\mu$ ), function of $i$ and $i$ takes values on a compact set, it must reach a unique maximum. Given $i_{1}$, it is easy to solve for the other unknowns. 


\section{References}

[1] Allen, F. and D. Gale, 1998, "Optimal financial crises." Journal of Finance 53, 1245-1284

[2] Antinolfi, G., E. Huybens and T. Keister, 2001, "Monetary stability and liquidity crises: The role of the lender of last resort." Journal of Economic Theory 99, 187-219.

[3] Bagehot, W., 1873, Lombard street, a description of the money market. (Scriber, Armstrong and Co, New York). References from the 1901 edition, Kegan Paul, Trench, Trüber and Co. Ltd. London.

[4] Bhattacharaya, S. and D. Gale, 1987, "Preference shocks, liquidity and central bank policy." In: W. Barnett and K. Singleton, eds., New approaches to monetary economics, (Cambridge University Press, Cambridge) 69-88.

[5] Bryant, J., and N. Wallace, 1980, "Open market operations in a model of regulated, insured intermediaries." Journal of Political Economy 88, 146-173.

[6] Chen, Y., 1999, "Banking panics: The role of the first-come, firts-serve rule and information externalities." Journal of Political Economy 107, 946-968.

[7] Cooper, R. and D. Corbae, 2000, "Financial collapse: A lesson from the great depression." Journal of Economic Theory 107, 159-190.

[8] Diamond, D. and P. Dybvig, 1983, "Bank runs, deposit insurance, and liquidity." Journal of Political Economy 91, 401-419.

[9] Fisher, S., 1999, "On the need for an international lender of last resort." Journal of Economic Perspective 13, 85-104.

[10] Freeman, S., 1996, "The payment system, liquidity and rediscounting." American Economic Review 86, 1126-1138.

[11] Freeman, S., 1999, "Redisounting under aggregate risk." Journal of Monetary Economics $43,197-216$.

[12] Goodhart, C., A., E., 1999, "Myths about the lender of last resort." International Finance 2, 339-360. 
[13] Green, E., J., 1997, "Money and debt in the structure of payments." Bank of Japan Monetary and Economic Studies 215, 63-87, reprinted in 1999, Quarterly Review, Federal Reserve Bank of Minneapolis, Spring, 13-29.

[14] Hirsh, F., 1977, "The Bagehot problem." The Manchester School Journal 45, 241-257.

[15] Humphrey, T., 1975, "The classical concept of the lender of last resort." Federal Reserve Bank of Richmond Economic Review 61, January/February, 2-9.

[16] Humphrey, T., and R. Keleher, 1984, "The lender of last resort: A historical perspective." Cato Journal 4, 275-318.

[17] Jacklin, C., 1987, "Demand deposits, trading restrictions, and risk sharing." In: E.C. Prescott and N. Wallace, eds., Contractual arrangements for intertemporal trade, (University of Minnesota Press, Minneapolis) 26-47.

[18] Laidler, D., 2002, "Two views of the lender of last resort: Thornton and Bagehot." Mimeo, University of Western Ontario.

[19] Lambertini, L., 2001, "Volatility and sovereign default." Mimeo, UCLA.

[20] McAndrews, J., and S. Potter, 2002, "Liquidity effects of the events of September 11, 2001." Federal Reserve Bank of New York Economic Policy Review 8, November.

[21] Markets Group of the Federal Reserve Bank of New York, 2002, "Domestic open market operations during 2001." Federal Reserve Bank of New York.

[22] Martin, A., 2001, "Liquidity provision vs. deposit insurance: preventing bank panics without moral hazard." working paper 01-05, Federal Reserve Bank of Kansas City.

[23] Redish, A., 2001, "Lender of last resort policies: From Bagehot to bailout." Mimeo, University of British Columbia.

[24] Repullo, R., 1999, "Who should act as lender of last resort? An incomplete contracts model." Journal of Money, Credit and Banking 32, 580-605.

[25] Rochet J.-C., and X. Vives, 2002, "Coordination failures and the lender of last resort: was Bagehot right after all?" Working paper, INSEAD. 
[26] Sheng, A., 1991, "Role of the central bank in banking crisis: An overview." In: P. Downes and R. Vaez-Zadeh, eds., The evolving role of central banks, (International Monetary Fund, Washington D.C.) 193-217.

[27] Summers, L., 1991, "Planning for the next financial crisis." In: M. Feldstein, ed., The risk of economic crisis, (The University of Chicago Press, Chicago) 135-158.

[28] Sleet, C. and B. Smith, 2000, "Deposit insurance and lender-of-last-resort functions." Journal of Money, Credit and Banking 32, 518-575.

[29] Thornton, H., 1802, An enquiry into the nature and effects of the paper credit of Great Britain. Reprinted in 1962, (Augustus M. Kelley, New York).

[30] Velde, F., R., and W. E. Weber, 2000, "A model of bimetallism." Journal of Political Economy 108, 1210-1234.

[31] Williamson, S., 1998, "Discount window lending and deposit insurance." Review of Economic Dynamic 1, 246-275. 